\title{
Hematite Nanoparticles Addition to Serpentine/Pyroxenes By-Products of Magnesite Mining Enrichment Process for the Production of Refractories
}

\author{
Kyriaki Kalaitzidou ${ }^{1, * \mathbb{D}}$, Evangelia Pagona ${ }^{1}$, Paraskevas Stratigousis ${ }^{1}$, Xanthi Ntampou ${ }^{1}$, Vasileios Zaspalis ${ }^{1}$, \\ Anastasios Zouboulis ${ }^{2}$ (D) and Manassis Mitrakas ${ }^{1}$ (D)
}

\section{check for}

updates

Citation: Kalaitzidou, K.; Pagona, E.; Stratigousis, P.; Ntampou, X.;

Zaspalis, V.; Zouboulis, A.; Mitrakas, M. Hematite Nanoparticles Addition to Serpentine/Pyroxenes By-Products of Magnesite Mining Enrichment Process for the Production of Refractories. Appl. Sci. 2022, 12, 2094. https://doi.org/ 10.3390/app12042094

Academic Editor: Ioanna Vasiliadou

Received: 29 December 2021

Accepted: 15 February 2022

Published: 17 February 2022

Publisher's Note: MDPI stays neutral with regard to jurisdictional claims in published maps and institutional affiliations.

Copyright: (C) 2022 by the authors. Licensee MDPI, Basel, Switzerland. This article is an open access article distributed under the terms and conditions of the Creative Commons Attribution (CC BY) license (https:// creativecommons.org/licenses/by/ $4.0 /)$.
1 Department of Chemical Engineering, School of Engineering, Aristotle University of Thessaloniki, 54124 Thessaloniki, Greece; evangelpg@cheng.auth.gr (E.P.); stratigop@cheng.auth.gr (P.S.); xntampou@cheng.auth.gr (X.N.); zaspalis@auth.gr (V.Z.); mmitraka@cheng.auth.gr (M.M.)

2 Department of Chemistry, School of Sciences, Aristotle University of Thessaloniki, 54124 Thessaloniki, Greece zoubouli@chem.auth.gr

* Correspondence: kalaitzidou@cheng.auth.gr

\begin{abstract}
The present study focuses on the refractory upgrade and reuse of the mining wastes/byproducts of the magnesite mine "Grecian Magnesite SA" (Chalkidiki, N. Greece), by the addition of hematite $\left(\alpha-\mathrm{Fe}_{2} \mathrm{O}_{3}\right)$ nanomaterial. These by-products were also examined after the application of thermal pre-treatment, i.e., treated at $850{ }^{\circ} \mathrm{C}$ for $30 \mathrm{~min}$, prior to sintering. Different thermal treatments and times were applied, aiming to induce the formation of forsterite and attempting to examine the respective effects on the refractory properties of up-cycled products. The results indicate that hematite addition of $5 \mathrm{wt} . \%$ can improve the major refractory parameters of products, whereas the applied thermal pre-treatment was not found to be particularly beneficial. Nevertheless, the optimum results were realized after thermal treatment at $1300{ }^{\circ} \mathrm{C}$ for 120 min heating time, also revealing that the initial mineralogical content of the examined mineral wastes is a key factor for the subsequent upgrade ranking of the final product.
\end{abstract}

Keywords: serpentinized mining waste; magnesite beneficiation by-products; $\mathrm{Fe}_{2} \mathrm{O}_{3}$ nanoparticles addition; thermal pre-treatment; refractory properties upgrade

\section{Introduction}

Currently, all industrial processes should be oriented towards the improvement of sustainability. Therefore, the reuse and/or recycling of by-products and wastes alongside economic interests are commonly required by applying circular economy principles. The mining waste is considered to be of particular interest due to the produced high mineral volumes. In this research, the upgrading of mineral wastes, produced in a magnesite mine ("Grecian Magnesite SA", Chalkidiki, N. Greece), due to the enrichment process of magnesite ore, are examined in order to improve the respective refractory properties and to recycle/reuse them for the production of useful products with economic value (e.g., bricks, metallurgical masses, etc. [1,2]). The main point is to properly apply the so-called "reverse mineralogy", i.e., to produce from the serpentized wastes the useful forsterite mineral phase $\left(\mathrm{Mg}_{2} \mathrm{SiO}_{4}\right)$, which is considered as a competitive refractory material [3]. The presence of other impurities, such as aluminum, calcium, and alkaline oxides in the initial serpentine/pyroxenes by-products, is generally unwanted because these constituents cannot efficiently be removed during the subsequently applied calcination process, and negatively affect the desirable refractory properties [4].

The detailed characterization of these wastes/by-products currently stocked in the magnesite mine area contain several impurities [1] and present rather low refractoriness; hence, the addition of another environmentally friendly and low-cost mineral/material 
that can enhance the refractory properties is required. It is also worth noting that several researchers utilized these serpentinized wastes for the re-formation of a (useful) forsterite mineral phase and the subsequent production of forsterite-based refractories (e.g., [4,5]). Thus, different additives, such as chromite [4], zirconia [6], aluminum titanate [3], magnesia [7], magnesium chloride hexahydrate [8], and iron oxides [9], etc., have been examined for this purpose. In present times, nanomaterials are considered as a specific material category, intensively investigated for the production of certain refractory materials due to their high surface to volume ratio which also increases the chemical reactivity and finally results in improved refractory products [10].

According to current trends, considering that the lifecycle of any product should potentially result in zero-waste production, in the present study the exploitation of mining wastes/by-products from a magnesite mine with the addition of the examined hematite nanoparticles, aimed to create improved refractory characteristics of the products. The role of hematite $\left(\mathrm{Fe}_{2} \mathrm{O}_{3}\right)$ is examined as a potential additive for the preparation of upgraded refractory materials after the application of appropriate thermal treatment processes. Iron oxide can promote the sintering of mineral grains with cation vacancies and, in the temperature range of $900{ }^{\circ} \mathrm{C}$ to $1200{ }^{\circ} \mathrm{C}$, reacts with the $\mathrm{MgO}$ content to form $\mathrm{MgFe}_{2} \mathrm{O}_{4}$, which is a high melting spinel phase [11]. During our previous studies [1,2], the detailed qualitative and quantitative characterization of magnesite mine solid wastes was performed, whereas in this study the effects of hematite addition on the main refractory properties of products are examined. Different thermal treatments were applied, i.e., $1300^{\circ} \mathrm{C}$ for 30 and $120 \mathrm{~min}$ and $1600{ }^{\circ} \mathrm{C}$ for $60 \mathrm{~min}$, attempting to examine the heating temperature and time in the main physicochemical properties improvement of products. Moreover, the by-products/samples were also examined after the application of a simple pre-treatment thermal procedure, i.e., the samples were thermally treated at $850{ }^{\circ} \mathrm{C}$ for $30 \mathrm{~min}$ to achieve the optimum forsterite formation prior to pelletization.

\section{Materials and Methods}

Different mineral waste samples were collected from various levels and positions from the magnesite mine area, and the most representatives were selected in terms of their mineral composition, showing different compositions of major constituents for comparison evaluations. The exact location of sampling sites is shown in Figure S1 (Supplementary Material). The mineralogical content (wt.\%) and the chemical composition of these samples are presented in Supplementary Material (Tables S1 and S2, respectively) [1]. Table S1 also contains extended information regarding the mineralogical content of the same samples but after the application of thermal treatment at $850^{\circ} \mathrm{C}$ for $30 \mathrm{~min}$, since these particular samples are also used as raw materials (i.e., prior to pelletization) for the hematite addition and the potential production of refractory materials, denoted hereafter as pre-treated samples (PT). The XRD measurement results in the semi-quantification of the crystalline phases (mineralogical content (wt.\%)), so the quantified values do not encounter the presence of amorphous $\mathrm{SiO}_{2}$ (also not initially considered, see the reaction 1) and as mentioned in the relevant published paper of Pagona et al., 2020 [1], there is a deviation in the obtained quantification results e.g., for the sample W5PT of 8.4\% (Table S2, Supplementary Material). The modification of raw serpentine mineral by the application of thermal treatment is shown in the following exothermic reaction and the formation of forsterite shown in Figure S2 (Supplementary Material) [1].

\section{$2\left[2 \mathrm{Mg}(\mathrm{OH})_{2} \cdot \mathrm{MgO} \cdot x \mathrm{SiO}_{2}\right] \rightarrow 3 \mathrm{Mg}_{2} \mathrm{SiO}_{4}+2(\mathrm{x}-3) \mathrm{SiO}_{2}+2 \mathrm{H}_{2} \mathrm{O}\left(\right.$ reaction 1 at $810-850{ }^{\circ} \mathrm{C}$ )}

Hematite applied as an additive for the examined mineral wastes, aiming to improve the physical properties of products before or after their initial thermal pre-treatment. Hematite $\left(\alpha-\mathrm{Fe}_{2} \mathrm{O}_{3}\right)$ nanoparticles were produced by the thermal treatment at $850{ }^{\circ} \mathrm{C}$ for $30 \mathrm{~min}$ of the commercially available nanomaterial Bayoxide, consisting mainly of goethite, and produced by LANXESS Deutschland $\mathrm{GmbH}$, as according to Gialanella et al., 2010, the transformation of goethite $(\mathrm{a}-\mathrm{FeOOH})$ into hematite $\left(\mathrm{a}-\mathrm{Fe}_{2} \mathrm{O}_{3}\right)$, occurs at about $300{ }^{\circ} \mathrm{C}$, and 
the respected XRD pattern to verify $\mathrm{Fe}_{2} \mathrm{O}_{3}$ formation is shown in Figure S3, Supplementary Material [12]. The initial material was further pulverized to obtain particle sizes $<73 \mu \mathrm{m}$ ) and a small quantity $(0.2 \mathrm{~g})$ was dissolved with $20 \mathrm{~mL} 6 \mathrm{~N} \mathrm{HCl}$ in Teflon vial on a sand bath and diluted to $200 \mathrm{~mL}$ with ultra-pure water. The chemical composition of obtained solution was determined by Flame Atomic Absorption Spectroscopy (FAAS), using the Perkin Elmer Atomic Absorption Spectrometer PinAAcle 500. The Loss-On-Ignition (LOI) test was determined at $950{ }^{\circ} \mathrm{C}$ in the electric furnace SNOL 6.7/1300LSC01. The respective results are presented in Table 1 . The LOI 1.1\% reported for the additive is attributed to the moisture absorbed during the cooling of the material after heating at $850{ }^{\circ} \mathrm{C}$.

Table 1. Chemical composition of hematite used as an additive in this research.

\begin{tabular}{lcccccccccc}
\hline Sample & $\mathrm{MgO}$ & $\mathrm{Cr}_{2} \mathrm{O}_{3}$ & $\mathrm{Al}_{2} \mathrm{O}_{3}$ & $\mathbf{C a O}$ & $\mathrm{Na}_{2} \mathrm{O}$ & $\mathrm{Fe}_{2} \mathrm{O}_{3}$ & $\mathrm{MnO}$ & $\mathbf{N i O}$ & $\mathrm{SiO}_{2}$ & LOI $^{\mathbf{1}}$ \\
\hline Hematite & 0.16 & $\mathrm{ND}^{2}$ & $\mathrm{ND}^{2}$ & 0.17 & 0.18 & 96.7 & 0.28 & 0.04 & 0.9 & 1.1 \\
\hline
\end{tabular}

${ }^{1}$ LOI: Loss-On-Ignition; ${ }^{2}$ Not detected.

The mining waste samples (W5, W6, W7 and W8) were subjected to co-grounding/rehomogenized with the hematite additive in different ratios of 5 and $10 \mathrm{wt} . \%$ after proper homogenization, and these percentages were properly selected because the $\mathrm{FeO}$ content in the initial mineral samples is already between 6.5-7.5 wt.\% (Table S2 Supplementary Material). All these mixtures (solid mineral powders) were homogenized subsequently with the help of a ball mill. The total weight of each blend was $5 \mathrm{~g}$. Therefore, the quantity of hematite (considering the ratios 5, and $10 \mathrm{wt} . \%$ ) was 0.25 and $0.5 \mathrm{~g}$ respectively, while the rest of the mixture was the examined mining sample. Afterwards, the ground/homogenized samples were pressed to form cylindrical pellets of $2 \mathrm{~cm}$ diameter. After the proper pelletization, these samples were thermally treated by using the programmable control electric furnace (type SNOL 6.7/1300 LSC01) for the maximum temperature $1300^{\circ} \mathrm{C}$ and by the Thermowatt TGH30L 380V 10KW furnace, when applying heating temperatures up to $1600^{\circ} \mathrm{C}$, to induce the formation of forsterite, consisting mainly of the useful olivine mineral phase. Different temperatures and times applied, i.e., $1300{ }^{\circ} \mathrm{C}$ for the duration of $30 \mathrm{~min}$, and $1600^{\circ} \mathrm{C}$ for $120 \mathrm{~min}$. The temperature was raised with the heating rate $10^{\circ} \mathrm{C} / \mathrm{min}$ up to $1300^{\circ} \mathrm{C}$ and with the heating rate $6.5^{\circ} \mathrm{C} / \mathrm{min}$ up to $1600^{\circ} \mathrm{C}$; afterwards, the samples were cooled to room temperature. The most important goal was to investigate the appropriately applied firing temperature that can upgrade these by-products so they can be further used as refractory materials after the respective thermal treatment. The new products can be used as refractory materials, when applicable for temperatures $\leq 1300{ }^{\circ} \mathrm{C}$, as shown also in the relevant preliminary previous study of Pagona et al. [1], where the addition of hematite was examined for its effect on the refractory properties of the products at $1300^{\circ} \mathrm{C}$ as well as at higher firing temperature (i.e., up to $1600{ }^{\circ} \mathrm{C}$ ). The appropriate thermal treatment also includes the examination of heating duration for the potential process improvement and for this reason two firing treatment times (i.e., 30 and $120 \mathrm{~min}$ ) were selected. The chemical compositions of examined blending as utilized for these experiments are shown in Table 2. The final content of iron oxides for the obtained products is increased up to $10.54-15.29 \mathrm{wt}$. $\%$. It is noticeable that the ratio of $\mathrm{MgO} / \mathrm{SiO}_{2}$ in the final samples is almost equal to the samples before the hematite addition, while at the same time the LOI is decreased respectively as expected due to the loss of water and crystal water of the samples.

Following the thermal treatment processes aiming to evaluate the refractory behavior of produced specimens, the main properties of interest determined, i.e., the apparent porosity $(\mathrm{AP} \%)$, the bulk density (BD) and the water absorption (WA\%), by using the boiling water method (ASTM C20) [13]. Moreover, the firing shrinkage (FS\%) was measured by a calibrated caliper along the diameter and using the $\left.\left(D_{0}-D_{1}\right) / D_{0}\right)$ ratio. The subscripts 0 and 1 refer to the sample dimensions before and after the thermal process. The images of 
samples' surfaces obtained by the Polarizing Optical Microscope (POM), and received with a ZEISS-POM camera, including a polarizer slit with a resolution of 20x. The mechanical strength tests were conducted with the use of a Carver laboratory press. Finally, the thermally treated pellets (i.e., the products) were also re-pulverized for their subsequent mineralogical characterization. The structural and mineralogical characterization of the fired samples and products were performed with the application of X-ray diffraction (XRD), using a Brücker D8 Advance diffractometer (powder XRD). The respective data collected at $2 \theta$ from $5^{\circ}$ to $70^{\circ}$, scan time $0.2 \mathrm{~s}$ and increment of 0.02 ; the filament $X$-ray tube of $\mathrm{Cu}$ with a wavelength $1.5418 \AA$ and the detector LYNXEYE (1D mode) used. The qualitative and quantitative analysis of XRD patterns were performed with the JADE XRD data analysis software.

Table 2. Chemical composition of the examined blended samples.

\begin{tabular}{cccccccc}
\hline Sample & $\mathbf{M g O}$ & $\mathbf{S i O}_{\mathbf{2}}$ & $\mathbf{F e O}$ & $\mathbf{A l}_{\mathbf{2}} \mathbf{O}_{3}$ & $\mathbf{C a O}$ & $\mathbf{C r}_{\mathbf{2}} \mathbf{O}_{3}$ & LOI \\
\hline & & & & $\mathbf{w t .} \%$ & & & \\
\hline $\mathrm{W} 5-5 \% \mathrm{Fe}_{2} \mathrm{O}_{3}$ & 39.72 & 37.29 & 11.30 & 0.43 & 0.44 & 0.03 & 8.91 \\
$\mathrm{W6-5} \% \mathrm{Fe}_{2} \mathrm{O}_{3}$ & 37.15 & 35.67 & 10.54 & 0.48 & 0.29 & 0.03 & 13.57 \\
$\mathrm{~W} 7-5 \% \mathrm{Fe}_{2} \mathrm{O}_{3}$ & 37.72 & 36.81 & 10.63 & 0.67 & 0.39 & 0.06 & 11.86 \\
$\mathrm{~W} 8-5 \% \mathrm{Fe}_{2} \mathrm{O}_{3}$ & 37.91 & 41.37 & 11.49 & 0.86 & 0.77 & 0.10 & 5.40 \\
$\mathrm{~W} 5-10 \% \mathrm{Fe}_{2} \mathrm{O}_{3}$ & 37.64 & 35.28 & 15.29 & 0.41 & 0.41 & 0.03 & 8.52 \\
$\mathrm{W6} 6-10 \% \mathrm{Fe}_{2} \mathrm{O}_{3}$ & 35.21 & 33.75 & 14.57 & 0.45 & 0.27 & 0.03 & 12.93 \\
$\mathrm{~W} 7-10 \% \mathrm{Fe}_{2} \mathrm{O}_{3}$ & 35.75 & 34.83 & 14.66 & 0.63 & 0.36 & 0.05 & 11.31 \\
$\mathrm{~W} 8-10 \% \mathrm{Fe}_{2} \mathrm{O}_{3}$ & 35.93 & 39.15 & 15.47 & 0.81 & 0.72 & 0.10 & 5.19 \\
\hline
\end{tabular}

\section{Results and Discussion}

\subsection{Microscopic Study}

After the applied thermal treatments and the subsequent cooling of products, their microstructure was examined respectively and is presented in Figures S4-S11, Supplementary material; selected representative micrographs are shown in Figure 1 regarding the application of different thermal treatments (temperatures and heating times).

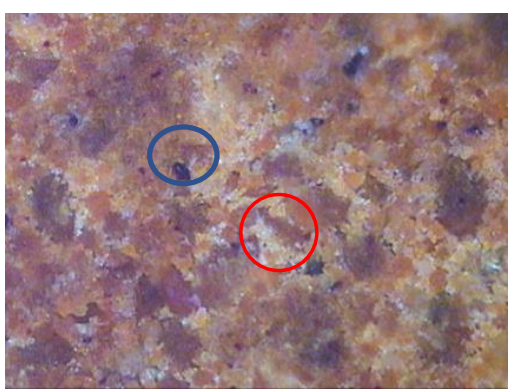

(a)

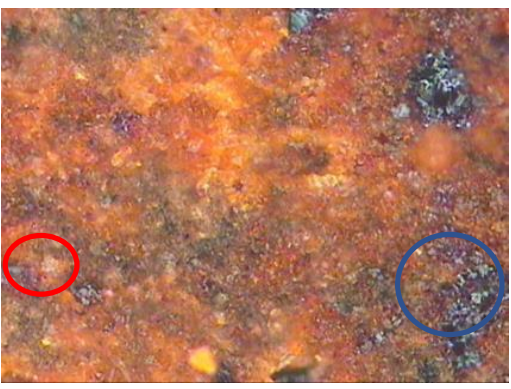

(c)

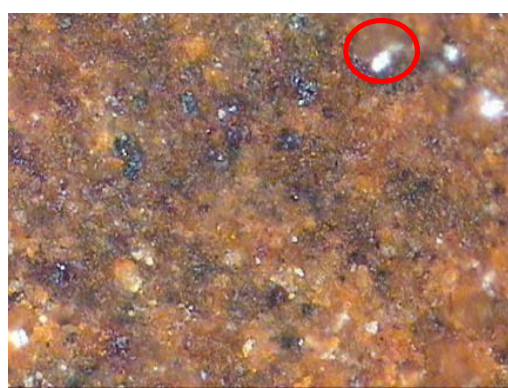

(b)

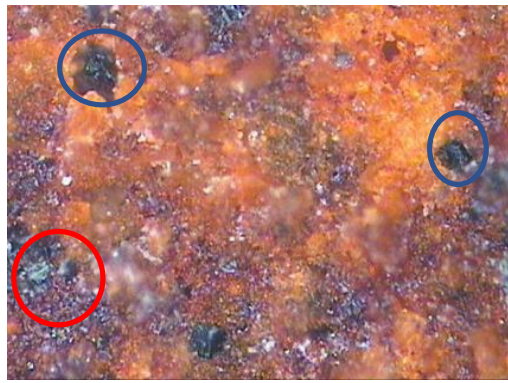

(d)

Figure 1. Cont. 


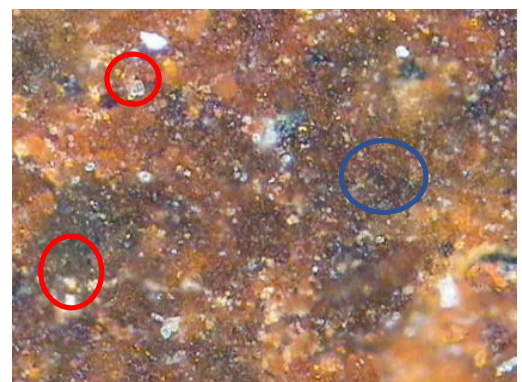

(e)

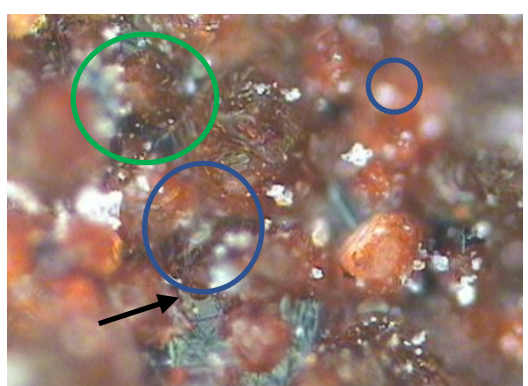

(f)

Figure 1. Optical microscope selected images (magnification: $\times 20$ ) of W5 sample: (a) raw/initial material, (b) with the addition of $5 \%$ wt. $\%$ hematite after firing at $1300{ }^{\circ} \mathrm{C}$ for $30 \mathrm{~min}$; (c) with the addition of $5 \%$ wt. $\%$ hematite, but after firing at $1300{ }^{\circ} \mathrm{C}$ for $120 \mathrm{~min}$; (d) thermally pre-treated at $850{ }^{\circ} \mathrm{C}$ for $30 \mathrm{~min}$ with the addition afterwards of $5 \% \mathrm{wt}$. hematite and after firing at $1300{ }^{\circ} \mathrm{C}$ for $120 \mathrm{~min}$; (e) with $10 \% \mathrm{wt} . \%$ hematite addition after firing at $1300{ }^{\circ} \mathrm{C}$ for $120 \mathrm{~min}$; and (f) with $5 \%$ wt. $\%$ hematite after firing at $1600{ }^{\circ} \mathrm{C}$ for $60 \mathrm{~min}$.

As it can be observed from Figure 1, the addition of hematite alters the surface of the obtained products/specimens. As a result of applied firing procedures, the granular content of samples presents differences regarding their surface compositions [14]. The white and black particles marked with red and blue circles in Figure 1 can be attributed to the presence of different crystalline phases. The major findings from the microscopic study of the products of the different thermal treatments of sample W5 (compared with the pre-treated product as well), are summarized below:

- Similarities are observed on the surface of products corresponding to the W5 sample with $5 \mathrm{wt} . \%$ of hematite addition and a thermal treatment of $30 \mathrm{~min}$ (Figure 1b), or of $120 \mathrm{~min}$ (Figure 1c)to the W5PT sample (again) with $5 \mathrm{wt} . \%$ hematite addition and thermal treatment of $120 \mathrm{~min}$ (Figure 1d).

- Moreover, the increase of hematite addition from 5 (Figure 1c) to $10 \mathrm{wt} . \%$ (Figure 1e) shows an increase of diverse mineral phases on the surface.

- Finally, comparing the different thermal treatments at the temperatures of $1300^{\circ}$ and $1600{ }^{\circ} \mathrm{C}$ (Figure $1 \mathrm{~d}$,f, respectively) it becomes obvious that at $1600{ }^{\circ} \mathrm{C}$ the granules obtained are larger, as compared with the thermal treatments at $1300^{\circ} \mathrm{C}$, while sintering is not sufficiently achieved even at the firing temperature of $1600^{\circ} \mathrm{C}$ (green circle), due to the increase of glassy phases.

The results are similar for all the samples examined, however with slightly different surface compositions showing an increase of the glassy phase when the thermal treatment is applied at $1600{ }^{\circ} \mathrm{C}$ (Figures S4-S11, Supplementary material).

\subsection{Measurements of Main Physical Properties of Products}

\subsubsection{Firing Shrinkage Parameter}

During the firing process the produced pellets are naturally shrinking, which is considered as an undesirable property for refractory applications, whereas the addition of hematite aims to minimize this shrinkage. Figure 2 shows the obtained results for each product from the raw examined samples W5, W6, W7, and W8 and the respective pre-treated ones when fired as with the addition of 0,5 and $10 \mathrm{wt} . \%$ hematite for the different thermal treatments applied at $1300{ }^{\circ} \mathrm{C}$ for $30 \mathrm{~min}$ and $120 \mathrm{~min}$, and at $1600{ }^{\circ} \mathrm{C}$ for $60 \mathrm{~min}$. The examined (four) samples present differences concerning the results of the firing shrinkage of products due to their initially different mineralogical content (see Table S1, Supplementary Material). As shown in Figure 2, the optimum results for each sample examined are:

- Regardless of the thermal pre-treatment (e.g., for sample W5), the firing with hematite addition was found to have a low shrinkage effect in the case of the firing of sample W5. 
Both the pre-treatment and hematite addition slightly increased the firing shrinkage of the products compared to the firing of the raw material, which is an undesirable outcome for the product.

- With regard to the samples W6 and W7 which both contained magnesite, which decomposes and reacts with hematite to form magnesioferrite, it therefore directly also affected the firing shrinkage [15]. The results showed that the firing shrinkage of products at $1300{ }^{\circ} \mathrm{C}$, containing 5 or $10 \mathrm{wt}$.\% hematite and pre-treated thermally at $850{ }^{\circ} \mathrm{C}$ for $30 \mathrm{~min}$ were almost equal to the firing shrinkages of the products without the addition of hematite.

- However, different results were found for the sample W8, which contains a higher percentage of pyroxenes, leading to lower shrinkage of products with the addition of hematite which were thermally treated at $1300{ }^{\circ} \mathrm{C}$ for $30 \mathrm{~min}$. Nevertheless, the results show the better sintering of the product obtained from the W8 sample after the application of thermal treatment at $1300{ }^{\circ} \mathrm{C}$ for $120 \mathrm{~min}$, hence presenting the lowest firing shrinkage.

- When the thermal treatment is applied at $1600{ }^{\circ} \mathrm{C}$ for $60 \mathrm{~min}$, the optimum results for the firing shrinkage parameter were detected for the product of the W8 sample containing $5 \mathrm{wt}$. $\% \mathrm{Fe}_{2} \mathrm{O}_{3}$ and for the thermally pre-treated W5, W6 and W7 samples.

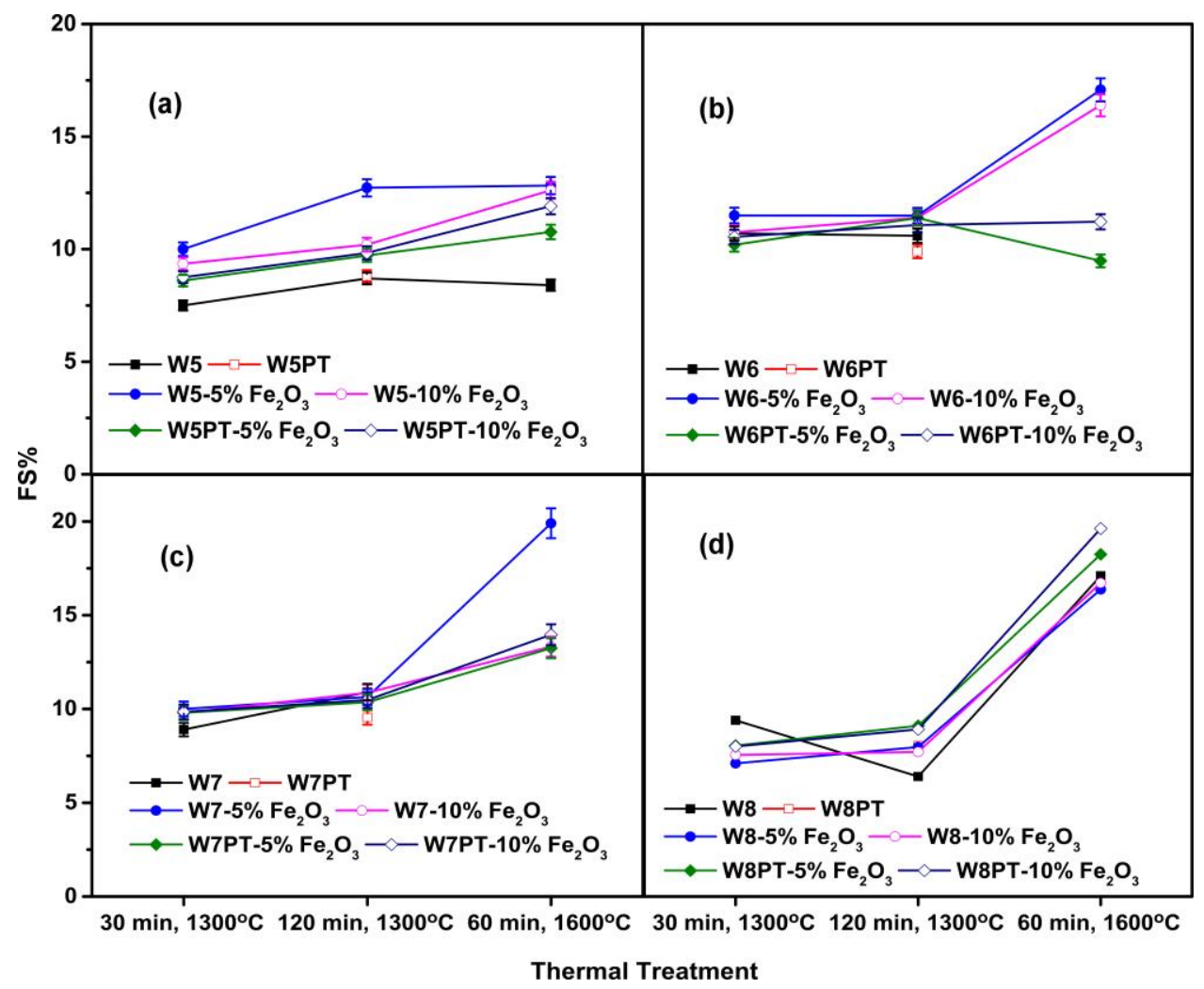

Figure 2. The firing shrinkage values (FS\%) of examined samples (thermally pre-treated or not), with or without the addition of hematite: (a) W5; (b) W6; (c) W7; (d) W8.

Figure 3 shows the comparison between the firing shrinkage results among the products of the fired samples regarding the addition of 5 or $10 \mathrm{wt} \%$ hematite, in order to evaluate the optimum raw material. It is obvious that for the thermal treatment at $1300{ }^{\circ} \mathrm{C}$ the sample W8 presents the lowest firing shrinkage. However, when the thermal treatment at $1600{ }^{\circ} \mathrm{C}$ is applied, then the firing shrinkage is doubled for this sample, whereas the minimum firing shrinkage (9.5\%) is shown for the sample W6PT with 5 wt.\% hematite addition. At this point is should be underlined that firing shrinkage values greater than $10 \%$ 
result in the failure of material, when applied as refractory, and this important parameter should be kept as small as possible for most refractory applications.

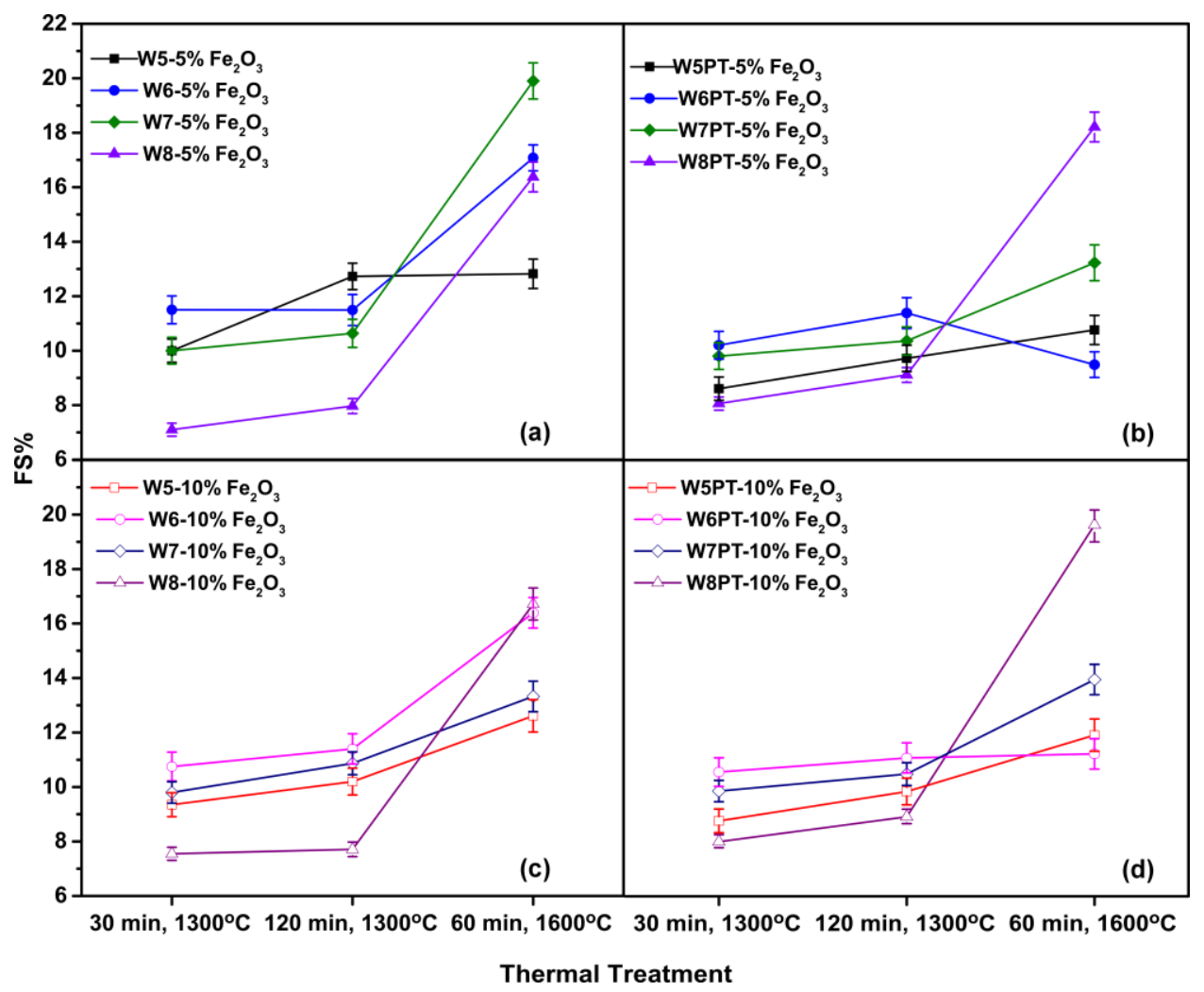

Figure 3. The firing shrinkage values (FS\%) of different samples: (a) with the addition of 5 wt.\% hematite; (b) thermally pre-treated samples with the addition also of $5 \mathrm{wt}$ \% hematite; (c) with the addition of $10 \mathrm{wt} . \%$ hematite; (d) thermally pre-treated samples with the addition of $10 \mathrm{wt} . \%$ hematite.

\subsubsection{Water Absorption (\%) and Apparent Porosity (\%) Parameters}

The water absorption (WA\%) and the apparent porosity ( $\mathrm{AP} \%$ ) results of fired products with the addition of hematite, and considering the thermal treatment at $1300{ }^{\circ} \mathrm{C}$ for $30 \mathrm{~min}$ are shown in Figure 4 for all the examined samples with or without the applied thermal pre-treatment. Forsterite bricks require apparent porosity values $<20 \%$ while increased apparent porosity levels constitute a negative factor, as the target of their production is to achieve the maximum bulk density which maximizes when apparent porosity is minimized [16]. The respective values of $\mathrm{WA} \%$ and $\mathrm{AP} \%$ with the addition of hematite show a slight decrease, with the highest decrease found for the sample W6, i.e., from $6.2 \%$ to $4.7 \%$ and from $16.2 \%$ to $13.3 \%$, respectively, which is attributed to the higher presence of magnesite in the W6 sample (see Table S1, Supplementary Material) which can react with hematite to form magnesioferrite spinel. It is noticeable that the lower porosity levels are reported for the pre-treated samples with the highest decrease shown for the sample W8, i.e., from $4.7 \%$ to $3.6 \%$ for the WA \% parameter and from $13.2 \%$ to $10.4 \%$ for the AP\% parameter, which can be attributed to the highest presence of pyroxenes in the thermally pre-treated sample (W8PT, see also see Table S1, Supplementary Material). The lower porosity levels correspond to higher bulk density values, whereas the higher porosity levels result in the opposite effect, indicating that the increase of hematite nanoparticles' addition (from 5 to $10 \mathrm{wt} \%$ ) and the pre-treatment at $850{ }^{\circ} \mathrm{C}$ can decrease both the WA(\%) and $\mathrm{AP}(\%)$ parameters. 


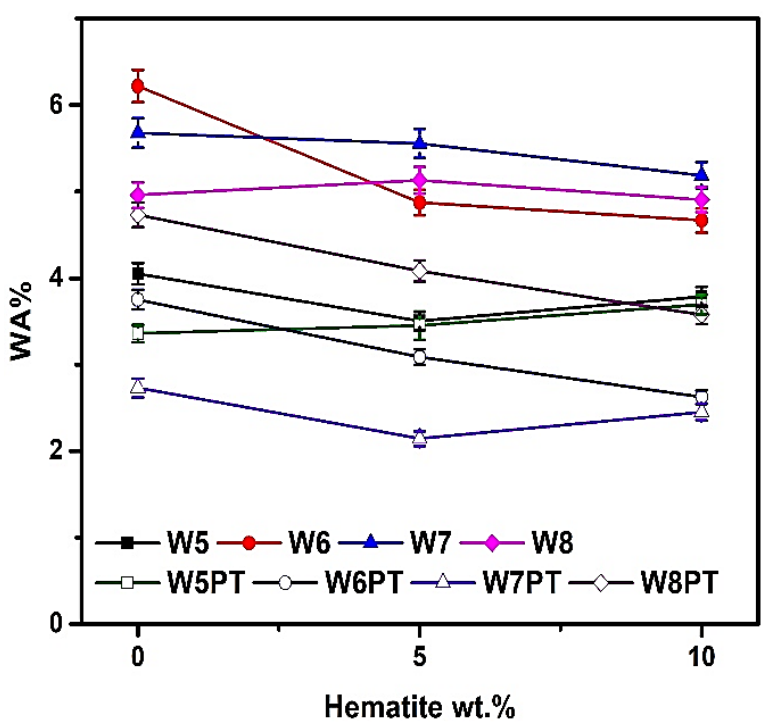

(a)

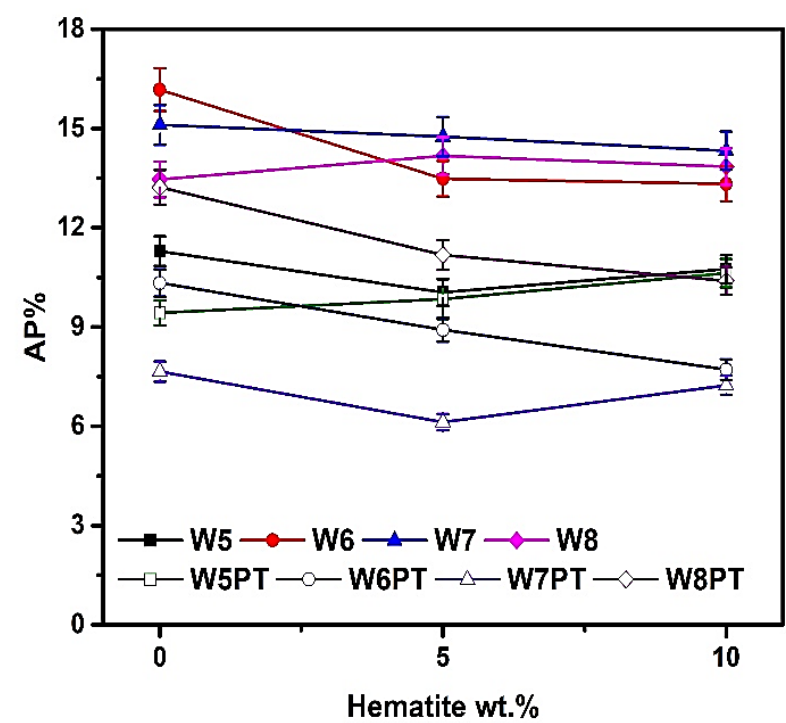

(b)

Figure 4. The effect of hematite addition on the values of (a) WA $\%$, and (b) AP\% parameters for the obtained products considering after the thermal treatment at $1300{ }^{\circ} \mathrm{C}$ for $30 \mathrm{~min}$.

\subsubsection{Bulk Density Parameter}

Since the target of refractory products is to achieve the maximum bulk density, the lower porosity is desirable [16]. Therefore, following the slight decreasing trend as shown in the aforementioned results of $\mathrm{WA}(\%)$ and $\mathrm{AP}(\%)$ parameters, the respective bulk density (BD) values are presented in Figure 5 regarding the thermal treatment at $1300^{\circ} \mathrm{C}$ for $30 \mathrm{~min}$ and for all the examined products, obtained either from the raw mineral samples (i.e., as collected directly from the mine area), as well as from the thermally pre-treated ones, showing an increasing trend in the final product, when increasing the hematite percentage for most of the examined samples, except for the sample W7. The BD values considering the hematite addition are similar to the BD levels of common magnesium refractories (i.e., $2.8-2.95 \mathrm{~g} / \mathrm{cm}^{3}$ ), whereas slightly higher values found for the thermally pre-treated samples (at $850{ }^{\circ} \mathrm{C}$ for $30 \mathrm{~min}$ ), prior to pelletization, due to the decrease of LOI values during the pre-heating procedure $[17,18]$. Finally, the optimum results, regarding the BD data, are observed for the sample W6PT, due to its higher content of (useful) olivine mineral formation, during the pre-treatment process due to the higher presence of $\mathrm{MgO}$ in the raw material.

As already mentioned by Gómez Rodríguez et al. (2015), the increase of bulk density can be either attributed to the higher true density of $\mathrm{Fe}_{2} \mathrm{O}_{3}\left(5.24 \mathrm{~g} / \mathrm{cm}^{3}\right)$ in comparison to $\mathrm{MgO}\left(3.58 \mathrm{~g} / \mathrm{cm}^{3}\right)$, or to the formation of respective $\mathrm{MgFe}_{2} \mathrm{O}_{4}$ spinel $\left(4.51 \mathrm{~g} / \mathrm{cm}^{3}\right)$ [15], along with the increase of relevant shrinkage values. Furthermore, the study of Azhari et al. (2009) showed that the formation of magnesioferrite spinel is encouraged at lower temperatures and in the presence of nano-iron oxide particles, since it decreases the eutectic temperature, hence improving the sintering process. Furthermore, it was also reported that the oxidation-reduction reactions, e.g., $\mathrm{Fe}^{2+}$ oxidizes to $\mathrm{Fe}^{3+}$ at $300{ }^{\circ} \mathrm{C}$, whereas $\mathrm{Fe}^{3+}$ reduces to $\mathrm{Fe}^{2+}$ at temperatures lower than $1400{ }^{\circ} \mathrm{C}$, are the main reasons for the differences in the volume of products [19]. Although existing in rather small percentages (around $5 \mathrm{wt} . \%$ ) in the product, the presence of hematite seems to facilitate the interconnection between the formed granules, thus increasing the bulk density as well as the mechanical strength of the produced fired materials. 


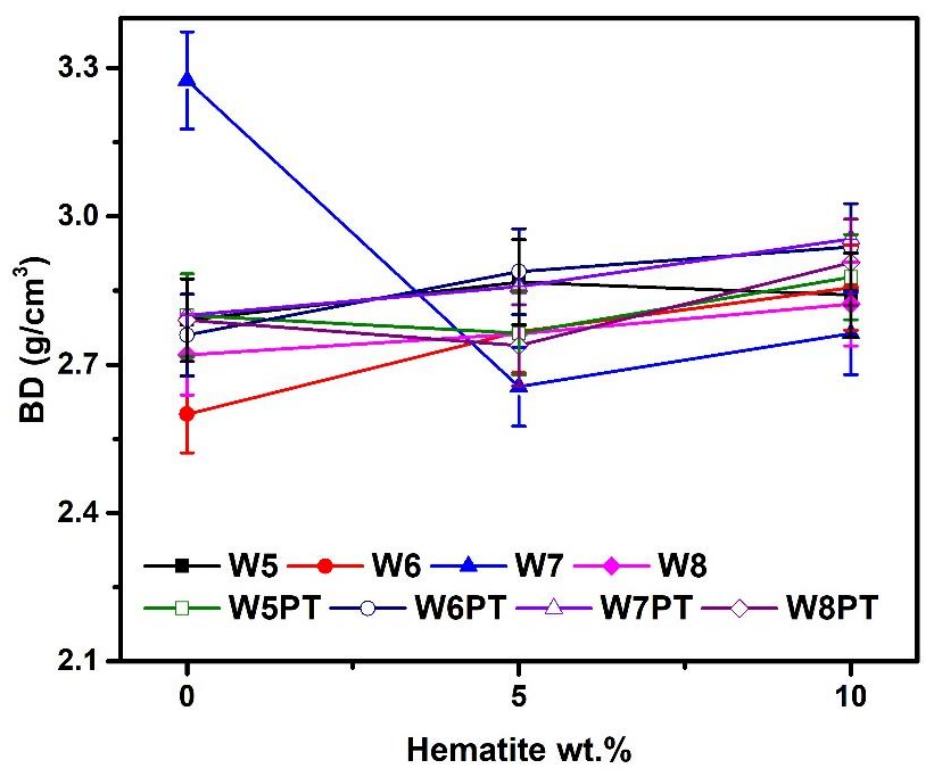

Figure 5. The effect of hematite addition (wt.\%) on the BD $\left(\mathrm{g} / \mathrm{cm}^{3}\right)$ parameter for the examined samples after the thermal treatment at $1300{ }^{\circ} \mathrm{C}$ for $30 \mathrm{~min}$.

\subsection{Mechanical Strength}

The results of compressive strength measurements are presented in Figure 6, showing that the mechanical strength of the obtained products is reaching maximum values after the application of thermal treatment at $1300^{\circ} \mathrm{C}$, with the optimum results shown for the W8 sample; the respective values under these conditions are greater than $120 \mathrm{MPa}$. The results also reveal that the hematite addition improves the mechanical strength with the optimum results found after the addition of $5 \mathrm{wt} . \% \mathrm{Fe}_{2} \mathrm{O}_{3}$ for all raw samples (i.e., those directly collected from the mine area), as well as after thermal treatment at $1300{ }^{\circ} \mathrm{C}$ for $120 \mathrm{~min}$. However, the sample W5PT, due to its different mineralogical content (containing almost $100 \%$ olivine) shows a slightly better mechanical strength even without the addition of hematite. Furthermore, it is noteworthy that the thermal pre-treatment (at $850{ }^{\circ} \mathrm{C}$ for $30 \mathrm{~min}$ ) of the examined samples does not favor significantly the mechanical strength values due to the higher presence of free silicon in these samples. Firing at temperatures higher than $1300{ }^{\circ} \mathrm{C}$ leads to the higher presence/formation of glassy phases, which reduce the bonding strength between the grain boundaries, resulting in lower mechanical strength and, hence, the respective product is not suitable as a refractory material, noting that the relevant limit is usually around $22 \mathrm{MPa}$ [20].

\subsection{XRD Phase Analysis of the Obtained Products after Firing under Different Conditions}

The XRD patterns of products obtained from the samples W5 and W5PT and with the addition of 5 or $10 \mathrm{wt} . \%$ hematite are shown in Figure 7, whereas the respected quantification of the mineral phases is presented in Table 3.

- These products (W5 and W5PT with hematite addition) were found to consist mainly of olivine (forsterite, forsterite ferroan), pyroxenes (clinoenstatite, protoenstatite, enstatite ferroan) and magnesioferrite.

- Comparing the products from sample W5 with that of sample W5PT, the olivine percentage is slightly higher in the product of the raw material, which was thermally pre-treated at $850{ }^{\circ} \mathrm{C}$ for $30 \mathrm{~min}$.

- For the products obtained from the W5 and W5PT samples, the results show that the final mineralogical content is similar for both applied thermal treatments (i.e., at $1300{ }^{\circ} \mathrm{C}$ for 30 and for $120 \mathrm{~min}$ ).

- The results show that the addition of hematite favors the formation of magnesioferrite spinel $\left(\mathrm{MgFe}_{2} \mathrm{O}_{4}\right)$, since the percentage of this constituent increases with the increase of hematite addition, while the percentage of (desirable) olivine (forsterite) as well 
as of (undesirable) pyroxenes (consisting mainly of enstatite) decreases due to the binding of magnesium by hematite in the respective crystalline phases.

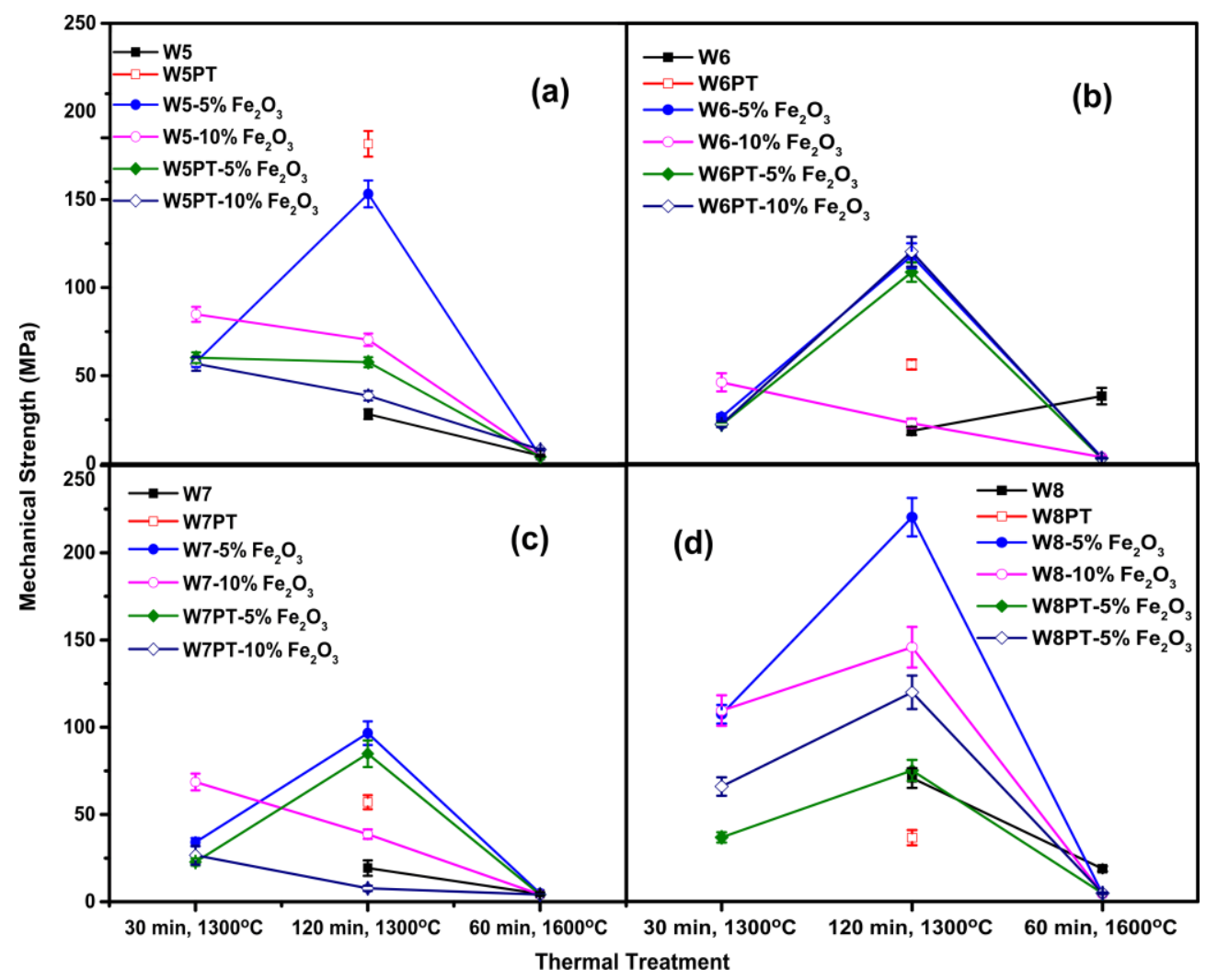

Figure 6. The mechanical strength values of examined samples (thermally pre-treated or not), with or without the addition of hematite: (a) W5; (b) W6; (c) W7; (d) W8.

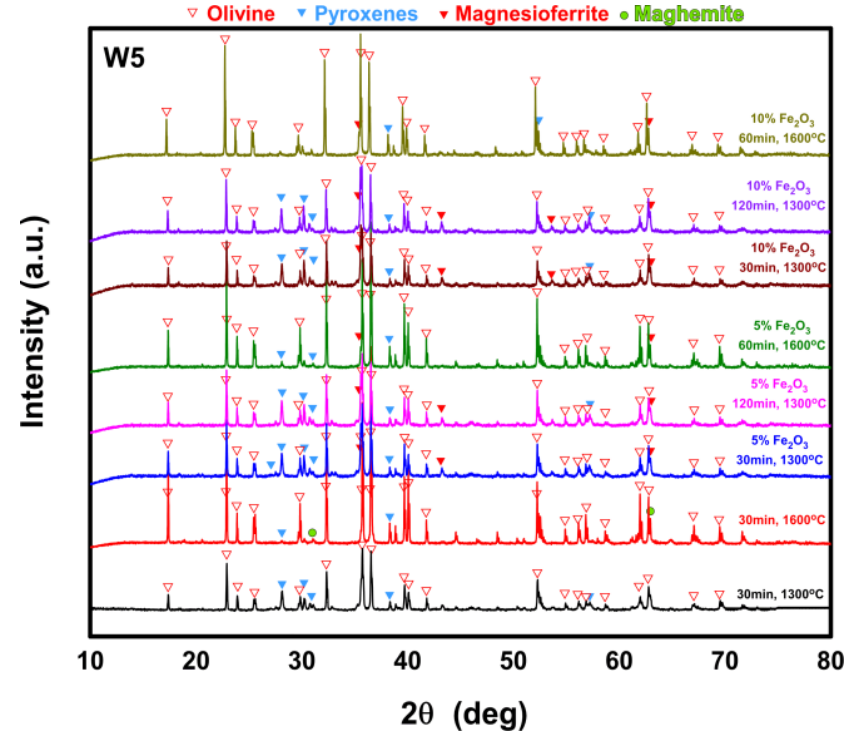

(a)

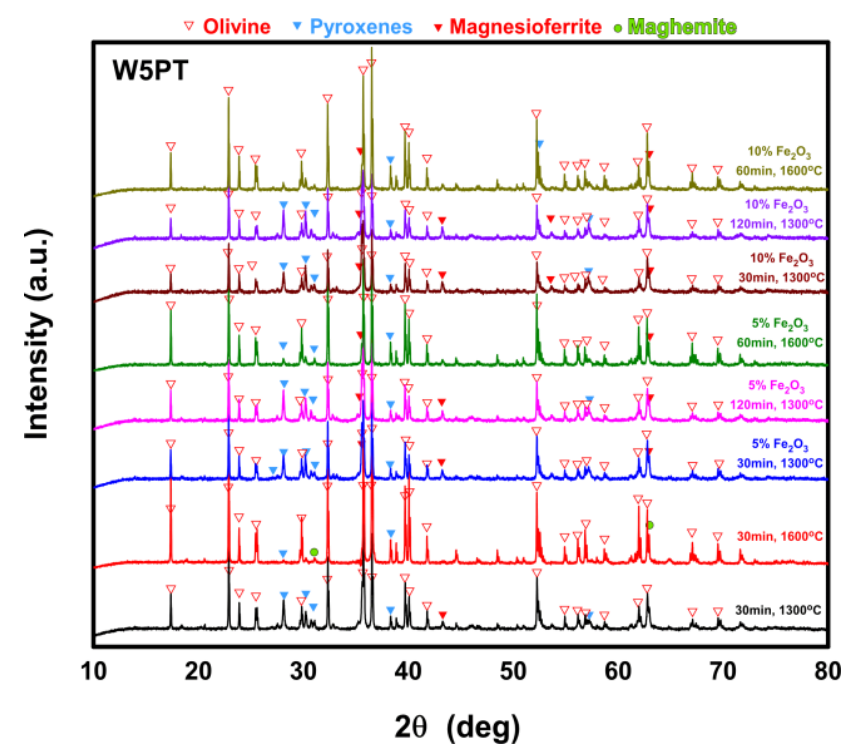

(b)

Figure 7. XRD patterns of the thermally treated products obtained from the respective samples: (a) W5, and (b) W5PT (with or without the presence of hematite). 
Table 3. The mineralogical content (wt.\%) of examined samples W5 and W5PT with the addition of hematite and after the application of different firing conditions.

\begin{tabular}{|c|c|c|c|c|}
\hline \multicolumn{5}{|c|}{ Sample W5 } \\
\hline \multicolumn{4}{|c|}{$1300{ }^{\circ} \mathrm{C}, 30 \mathrm{~min}$} & $1600{ }^{\circ} \mathrm{C}, 60 \mathrm{~min}$ \\
\hline Forsterite & \multirow{3}{*}{\multicolumn{2}{|c|}{$\begin{array}{l}72.6 \pm 5.2 \\
27.4 \pm 3.1\end{array}$}} & Forsterite Ferroan & $93.3 \pm 6.7$ \\
\hline Enstatite Ferroan & & & Clinoenstatite & $2.8 \pm 0.7$ \\
\hline & & & Maghemite & $3.9 \pm 0.8$ \\
\hline \multicolumn{5}{|c|}{ Sample W5-5\% $\mathrm{Fe}_{2} \mathrm{O}_{3}$} \\
\hline & $1300{ }^{\circ} \mathrm{C}, 30 \mathrm{~min}$ & $1300{ }^{\circ} \mathrm{C}, 120 \mathrm{~min}$ & & $1600{ }^{\circ} \mathrm{C}, 60 \mathrm{~min}$ \\
\hline Forsterite Ferroan & $64.3 \pm 4.6$ & $63.2 \pm 4.5$ & Forsterite Ferroan & $90.6 \pm 6.6$ \\
\hline Protoenstatite & $19.9 \pm 1.2$ & $21.4 \pm 1.2$ & Clinoenstatite & $4.8 \pm 0.6$ \\
\hline Magnesioferrite & $15.8 \pm 1.6$ & $15.4 \pm 1.6$ & Magnesioferrite & $4.6 \pm 0.6$ \\
\hline \multicolumn{5}{|c|}{ Sample W5-10\% $\mathrm{Fe}_{2} \mathrm{O}_{3}$} \\
\hline & $1300{ }^{\circ} \mathrm{C}, 30 \mathrm{~min}$ & $1300^{\circ} \mathrm{C}, 120 \mathrm{~min}$ & & $1600{ }^{\circ} \mathrm{C}, 60 \mathrm{~min}$ \\
\hline Forsterite Ferroan & $58.5 \pm 3.9$ & $58.5 \pm 3.9$ & Forsterite Ferroan & $90.0 \pm 6.3$ \\
\hline Protoenstatite & $21.1 \pm 1.9$ & $21.1 \pm 1.9$ & Clinoenstatite & $2.7 \pm 0.6$ \\
\hline Magnesioferrite & $20.4 \pm 1.4$ & $20.4 \pm 1.4$ & Magnesioferrite & $7.2 \pm 1.1$ \\
\hline \multicolumn{5}{|c|}{ Sample W5PT } \\
\hline \multicolumn{4}{|c|}{$1300^{\circ} \mathrm{C}, 30 \mathrm{~min}$} & $1600{ }^{\circ} \mathrm{C}, 60 \mathrm{~min}$ \\
\hline Forsterite & \multirow{3}{*}{\multicolumn{2}{|c|}{$\begin{array}{l}73.7 \pm 5.2 \\
23.3 \pm 2.6\end{array}$}} & Forsterite Ferroan & $93.3 \pm 6.6$ \\
\hline Enstatite Ferroan & & & Clinoenstatite & $2.8 \pm 0.6$ \\
\hline & & & Magnesioferrite & $3.9 \pm 0.6$ \\
\hline \multicolumn{5}{|c|}{ Sample $\mathrm{W} 5 \mathrm{PT}-5 \% \mathrm{Fe}_{2} \mathrm{O}_{3}$} \\
\hline & $1300{ }^{\circ} \mathrm{C}, 30 \mathrm{~min}$ & $1300{ }^{\circ} \mathrm{C}, 120 \mathrm{~min}$ & & $1600{ }^{\circ} \mathrm{C}, 60 \mathrm{~min}$ \\
\hline Forsterite Ferroan & $69.4 \pm 4.5$ & $67.8 \pm 4.3$ & Forsterite Ferroan & $88.6 \pm 6.3$ \\
\hline Protoenstatite & $14.8 \pm 1.0$ & $16.8 \pm 1.1$ & Clinoenstatite & $5.9 \pm 0.9$ \\
\hline Magnesioferrite & $15.8 \pm 1.6$ & $15.3 \pm 1.6$ & Magnesioferrite & $5.5 \pm 0.9$ \\
\hline \multicolumn{5}{|c|}{ Sample W5PT-10\% $\mathrm{Fe}_{2} \mathrm{O}_{3}$} \\
\hline & $1300{ }^{\circ} \mathrm{C}, 30 \mathrm{~min}$ & $1300^{\circ} \mathrm{C}, 120 \mathrm{~min}$ & & $1600{ }^{\circ} \mathrm{C}, 60 \mathrm{~min}$ \\
\hline Forsterite Ferroan & $64.1 \pm 4.6$ & $64.2 \pm 4.6$ & Forsterite Ferroan & $89.7 \pm 6.5$ \\
\hline Protoenstatite & $13.8 \pm 1.2$ & $17.3 \pm 1.3$ & Clinoenstatite & $4.5 \pm 0.8$ \\
\hline Magnesioferrite & $22.2 \pm 1.5$ & $18.4 \pm 1.4$ & Magnesioferrite & $5.8 \pm 0.9$ \\
\hline
\end{tabular}

Since the magnesioferrite spinel has a melting point close to that of olivine (forsterite), and according to the respective phase equilibrium diagram for the system $\mathrm{MgFe}_{2} \mathrm{O}_{4}$ $\mathrm{Mg}_{2} \mathrm{SiO}_{4}$ (see the supplementary material, Figure S12) the decrease of the enstatite percentage is expected to upgrade the refractory properties. More specifically, the melting temperature of forsterite is $1890^{\circ} \mathrm{C}$, whereas the temperature of incongruent melting and liquidus state for the magnesioferrite are $1713^{\circ} \mathrm{C}$ and about $1900^{\circ} \mathrm{C}$, respectively, and in the spinels' system $\mathrm{MgFe}_{2} \mathrm{O}_{4}-\mathrm{Mg}_{2} \mathrm{SiO}_{4}$ the initial melting point occurs at $1665 \pm 10{ }^{\circ} \mathrm{C}$, although, as already mentioned, this temperature is reduced at values lower than $1600{ }^{\circ} \mathrm{C}$ when the iron oxide is added $[19,21]$.

The results that show the increase of magnesioferrite in the product by the addition of hematite nanoparticles addition are in accordance with the study of Khisina et al., 1994 which reported that by applying annealing temperatures up to $700{ }^{\circ} \mathrm{C}$ for the $\mathrm{Mg}$-Fe Olivine mineral, oxidation results in the formation of magensioferrite (as the major oxide phase among the different ferrous oxide phases formed) [22]. The study by Acar, 2020 showed that the ratios of $\mathrm{MgO} / \mathrm{SiO}_{2}$ and $\mathrm{MgO} / \mathrm{FeO}$ are the main determinant factors for magnesioferrite formation [23]. Moreover, Rietmeijer et al., 2013 also reported magnesioferrite formation when $\mathrm{Fe}^{0}$ reacted with brucite $\mathrm{Mg}(\mathrm{OH})_{2}$ [24]. The formation of magnessioferrite with the addition of nano- $\mathrm{Fe}_{2} \mathrm{O}_{3}$ due to its high solubility and atomic mobility in magnesia substrate was also reported by Gómez Rodríguez et al., 2015 [15]. Finally, according to Semberg et al. 
(2011), the olivine particles after oxidation decompose along the particle boundary and transform to magnesioferrite crystals and pyroxene/vitreous silica, while at the same time a part of hematite can diffuse into their structure, as this presents rather high solubility in the presence of $\mathrm{MgO}$ [25].

At this point it must be underlined that the quantification of mineralogical phases as obtained from the XRD patterns, and the thermal treatment at $1600{ }^{\circ} \mathrm{C}$ refers only to the detected crystalline phases and is not representative of the overall content of the product, since there is also a high percentage of glassy phase due to the eutectic phases at the heating temperature of $1600{ }^{\circ} \mathrm{C}$, which is not detected by the XRD measurements.

Magnesium silicate polymorphism is observed when the samples are subjected to the thermal treatments applied in this study, and this is a matter of particular interest, as its polymorphism is a field of study that has not yet been thoroughly investigated. When heating at temperatures higher than $1200{ }^{\circ} \mathrm{C}$, free silica and iron oxide reacts with forsterite to form magnessioferrite and polymorphic modifications of magnesium silicate, $\mathrm{MgSiO}_{3}$ as enstatite protoenstatite and clinoenstatite [26]. Polymorphism for enstatite, protoenstatite, clinoenstatite and high temperature clinoenstatite was studied by Mielcarek et al., 2004, who reported that protoenstatite crystallization starts at temperatures above $1250{ }^{\circ} \mathrm{C}$ and fully develops at $1420^{\circ} \mathrm{C}$, and that at higher heating temperatures protoenstatite crystallites are unstable and they inverse to clinoenstatite crystallites after cooling [27]. Even very low mechanical stresses may transform protoenstatite into clinoenstatite, a transformation that leads to negative volume changes and mechanical strength $[27,28]$. Thus, the enstatite of the raw materials similar to several studies [29-32] is transformed to protoenstatite or to clinoenstatite accompanied by the residual protoenstatite when the applied thermal treatment is at $1300{ }^{\circ} \mathrm{C}$ [30], and to clinoenstatite (during the cooling) when the applied thermal treatment is at $1600{ }^{\circ} \mathrm{C}$. Figures S13-S16 in the Supplementary Material show the detailed identification of the magnesium silicate polymorphs.

Similar results to the products obtained from the sample W5 are also found for the products of sample W6 (Figure 8), whereas the respected mineral content is presented in Table 4.

- These products (W6 with hematite addition) were found to consist mainly of olivine (forsterite, forsterite ferroan), pyroxenes (clinoenstatite, protoenstatite) and magnesioferrite.

- As aforementioned, the addition of hematite favors the formation of magnesioferrite spinel $\left(\mathrm{MgFe}_{2} \mathrm{O}_{4}\right)$, as the percentage of this constituent increases with the increase of hematite addition, while the percentage of olivine (forsterite) and of pyroxenes (enstatite) decreases.

- For the products obtained from the W6 sample, it was found that the final mineralogical content is similar for both applied thermal treatments (i.e., at $1300{ }^{\circ} \mathrm{C}$ for 30 or $120 \mathrm{~min}$ ).

Figure 9 shows the XRD patterns for the products obtained from the thermally treated sample W7, whereas the respective mineral content is presented in Table 5.

- These products with hematite addition were found to consist mainly of olivine (forsterite, forsterite ferroan), pyroxenes (clinoenstatite, protoenstatite) and magnesioferrite.

- As shown from the quantification results, the heating time of $30 \mathrm{~min}$ is not considered as sufficient for the hematite additive to react and form the maximum quantity of magnesioferrite in the final product, probably due to the different initial mineralogical content of this sample (W7)—see also Table S1, Supplementary Material.

- Moreover, the respective quantification shows that a part of olivine (forsterite) and a part of the pyroxenes (enstatite) also react with hematite to form magnesioferrite, resulting in the decrease of olivine and pyroxenes content alongside a simultaneous increase of magnesioferrite formation in the final product obtained from the W7 sample. 


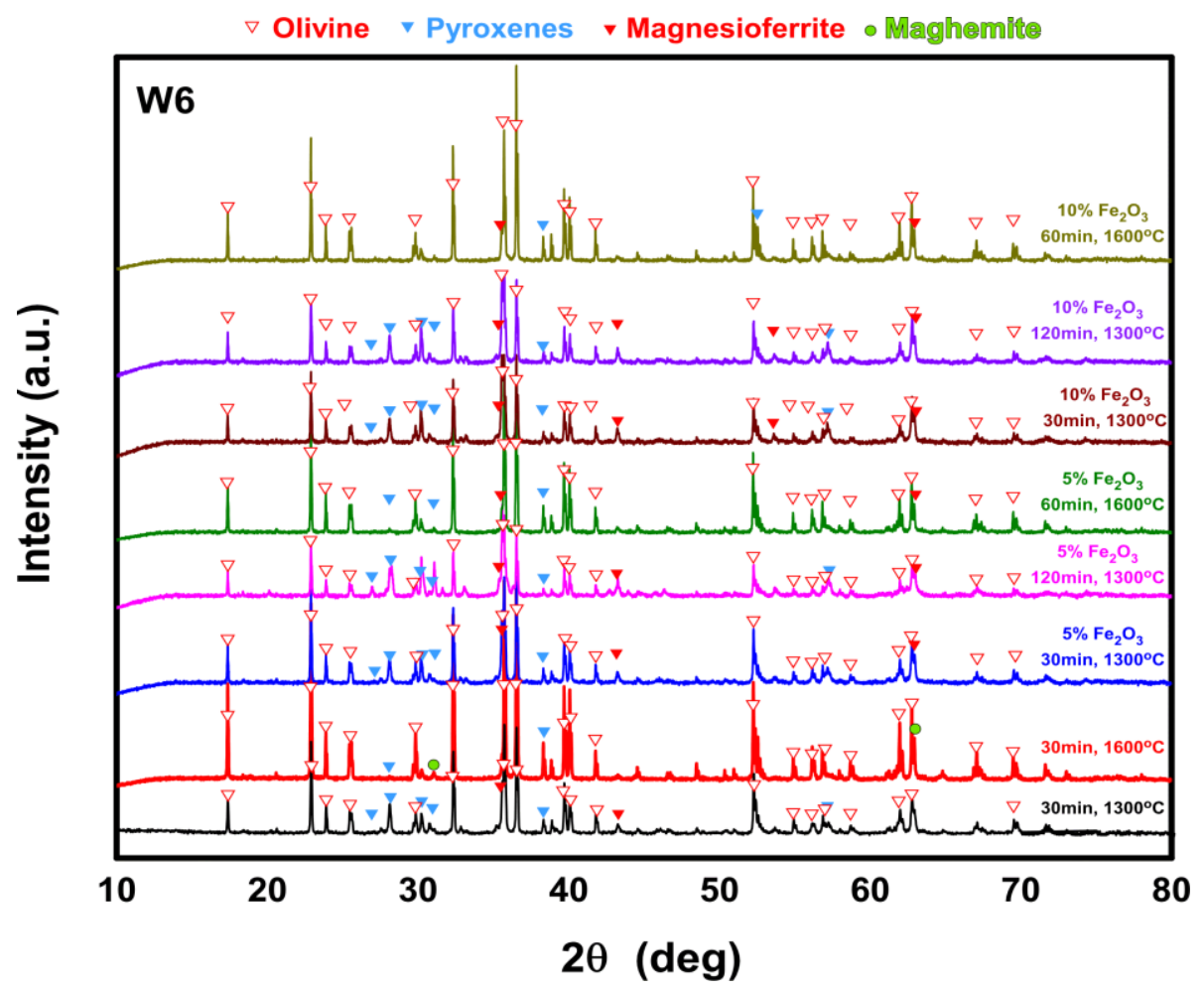

Figure 8. XRD patterns of thermally obtained products from sample W6 under different firing conditions with and without the addition of hematite.

Table 4. The mineralogical content (wt.\%) of examined samples W6 and W6PT with the addition of hematite and after the application of different firing conditions.

\begin{tabular}{|c|c|c|c|c|}
\hline \multicolumn{5}{|c|}{ Sample W6 } \\
\hline \multicolumn{4}{|c|}{$1300{ }^{\circ} \mathrm{C}, 30 \mathrm{~min}$} & $1600^{\circ} \mathrm{C}, 60 \mathrm{~min}$ \\
\hline Forsterite & \multirow{3}{*}{\multicolumn{2}{|c|}{$\begin{array}{c}73.7 \% \pm 5.2 \\
26.3 \% \pm 2.6 \\
1.9 \% \pm 0.6\end{array}$}} & Forsterite & $93.3 \pm 6.6$ \\
\hline Enstatite & & & Clinoenstatite & $2.2 \pm 0.6$ \\
\hline Stishovite & & & Maghemite & $4.5 \pm 0.6$ \\
\hline \multicolumn{5}{|c|}{ Sample W6-5\% $\mathrm{Fe}_{2} \mathrm{O}_{3}$} \\
\hline \multicolumn{4}{|c|}{$1300^{\circ} \mathrm{C}, 120 \mathrm{~min}$} & $1600^{\circ} \mathrm{C}, 60 \mathrm{~min}$ \\
\hline Forsterite Ferroan & $70.1 \pm 5.2$ & $69.8 \pm 5.2$ & Forsterite Ferroan & $89.9 \pm 6.3$ \\
\hline Protoenstatite & $15.9 \pm 1.1$ & $16.0 \pm 1.1$ & Clinoenstatite & $2.1 \pm 0.6$ \\
\hline Magnesioferrite & $14.0 \pm 1.5$ & $14.1 \pm 1.5$ & Magnesioferrite & $8.0 \pm 0.9$ \\
\hline \multicolumn{5}{|c|}{ Sample W6-10\% $\mathrm{Fe}_{2} \mathrm{O}_{3}$} \\
\hline & $1300{ }^{\circ} \mathrm{C}, 30 \mathrm{~min}$ & $1300^{\circ} \mathrm{C}, 120 \mathrm{~min}$ & & $1600^{\circ} \mathrm{C}, 60 \mathrm{~min}$ \\
\hline Forsterite Ferroan & $63.8 \pm 5.0$ & $62.5 \pm 5.0$ & Forsterite Ferroan & $91.6 \pm 6.5$ \\
\hline Protoenstatite & $15.7 \pm 1.1$ & $17.1 \pm 1.2$ & Clinoenstatite & $2.6 \pm 0.5$ \\
\hline Magnesioferrite & $20.5 \pm 1.5$ & $20.5 \pm 1.5$ & Magnesioferrite & $5.8 \pm 0.7$ \\
\hline
\end{tabular}




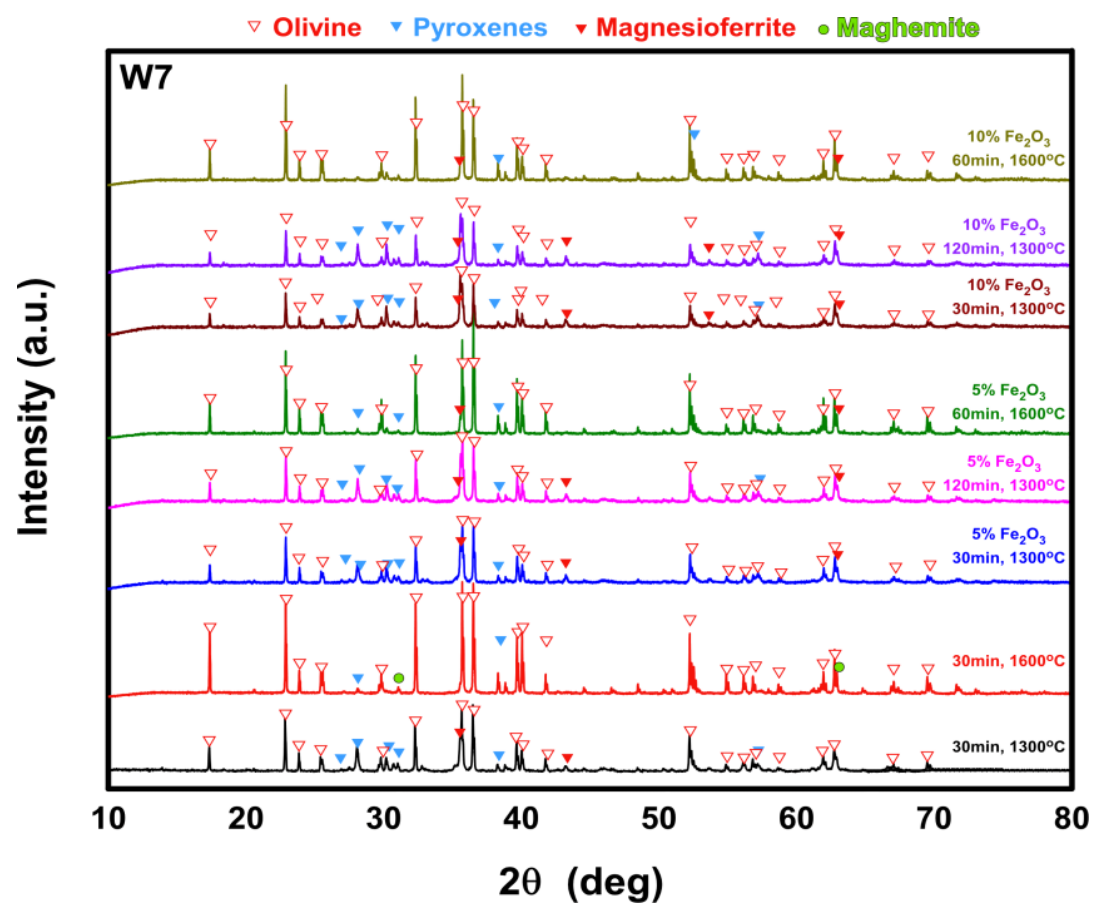

Figure 9. XRD patterns of thermally obtained product from sample W7 under different firing conditions with and without the addition of hematite.

Table 5. The mineralogical content (wt.\%) of product obtained from the sample W7 with the addition of hematite after firing.

\begin{tabular}{|c|c|c|c|c|c|}
\hline \multicolumn{6}{|c|}{ Sample W7 } \\
\hline \multicolumn{5}{|c|}{$1300^{\circ} \mathrm{C}, 30 \mathrm{~min}$} & $1600^{\circ} \mathrm{C}, 60 \mathrm{~min}$ \\
\hline Forsterite & \multirow{2}{*}{\multicolumn{3}{|c|}{$\begin{array}{l}62.2 \% \pm 4.3 \\
37.8 \% \pm 3.1\end{array}$}} & Forsterite & $91.6 \pm 6.7$ \\
\hline Enstatite & & & & $\begin{array}{l}\text { Clinoenstatite } \\
\text { Maghemite }\end{array}$ & $\begin{array}{l}4.0 \pm 0.4 \\
4.4+0.7\end{array}$ \\
\hline \multicolumn{6}{|c|}{ Sample $\mathrm{W} 7-5 \% \mathrm{Fe}_{2} \mathrm{O}_{3}$} \\
\hline & $1300^{\circ} \mathrm{C}, 30 \mathrm{~min}$ & & $1300^{\circ} \mathrm{C}, 120 \mathrm{~min}$ & & $1600^{\circ} \mathrm{C}, 60 \mathrm{~min}$ \\
\hline $\begin{array}{l}\text { Forsterite } \\
\text { Ferroan }\end{array}$ & $71.4 \pm 4.7$ & $\begin{array}{l}\text { Forsterite } \\
\text { Ferroan }\end{array}$ & $61.4 \pm 4.2$ & $\begin{array}{c}\text { Forsterite } \\
\text { Ferroan }\end{array}$ & $92.5 \pm 6.8$ \\
\hline Clinoenstatite & $11.0 \pm 1.0$ & Protoenstatite & $22.3 \pm 1.4$ & Clinoenstatite & $3.9 \pm 0.4$ \\
\hline Magnesioferrite & $17.6 \pm 1.2$ & Magnesioferrite & $16.3 \pm 1.3$ & Magnesioferrite & $3.6 \pm 0.3$ \\
\hline \multicolumn{6}{|c|}{ Sample W7-10\% $\mathrm{Fe}_{2} \mathrm{O}_{3}$} \\
\hline & $1300^{\circ} \mathrm{C}, 30 \mathrm{~min}$ & & $1300^{\circ} \mathrm{C}, 120 \mathrm{~min}$ & & $1600^{\circ} \mathrm{C}, 60 \mathrm{~min}$ \\
\hline $\begin{array}{l}\text { Forsterite } \\
\text { Ferroan }\end{array}$ & $66.2 \pm 4.6$ & $\begin{array}{l}\text { Forsterite } \\
\text { Ferroan }\end{array}$ & $56.0 \pm 4.3$ & $\begin{array}{l}\text { Forsterite } \\
\text { Ferroan }\end{array}$ & $88.7 \pm 6.5$ \\
\hline Clinoenstatite & $9.3 \pm 1.1$ & Protoenstatite & $23.5 \pm 1.4$ & Clinoenstatite & $3.4 \pm 0.4$ \\
\hline Magnesioferrite & $24.5 \pm 1.5$ & Magnesioferrite & $20.5 \pm 1.5$ & Magnesioferrite & $7.9 \pm 0.5$ \\
\hline
\end{tabular}

Finally, Figure 10 shows the XRD patterns for the thermally treated sample W8, whereas the respective mineral content is presented in Table 6 .

- These products with hematite addition were found to consist mainly of olivine (forsterite, forsterite ferroan), pyroxenes (clinoenstatite, protoenstatite, enstatite ferroan) and magnesioferrite.

- The mineralogical content of the obtained products show a significantly higher percentage of pyroxenes' presence, as compared to samples W5, W5PT, W6 and W7, due to the initial mineralogically different content of this sample (W8, see also Table S1, Supplementary Material), which contains a higher percentage of pyroxenes. 


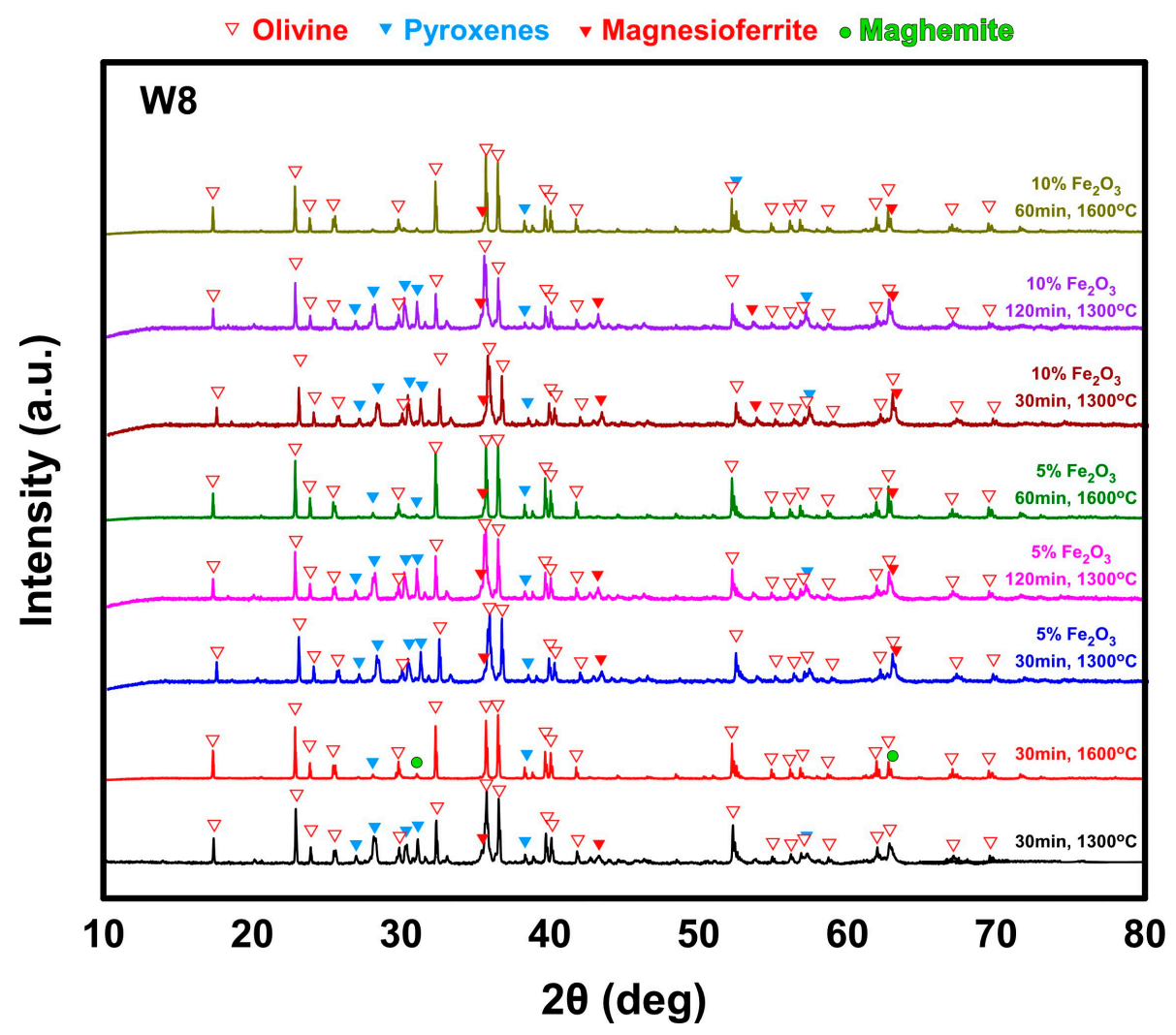

Figure 10. XRD patterns of the product obtained from the sample W8 under different firing conditions with and without the addition of hematite.

Table 6. The mineralogical content (wt.\%) of product obtained from the sample W8 with the addition of hematite after firing.

\begin{tabular}{|c|c|c|c|c|c|}
\hline \multicolumn{6}{|c|}{ Sample W8 } \\
\hline \multicolumn{5}{|c|}{$1300^{\circ} \mathrm{C}, 30 \mathrm{~min}$} & $1600{ }^{\circ} \mathrm{C}, 60 \mathrm{~min}$ \\
\hline Forsterite & \multirow{3}{*}{\multicolumn{3}{|c|}{$\begin{array}{l}53.8 \% \pm 3.8 \\
46.2 \% \pm 3.5\end{array}$}} & Forsterite & $81.2 \% \pm 6.0$ \\
\hline Enstatite & & & & Enstatite & $15.5 \% \pm 1.1$ \\
\hline & & & & Maghemite & $3.3 \% \pm 0.5$ \\
\hline \multicolumn{6}{|c|}{ Sample W8-5\% $\mathrm{Fe}_{2} \mathrm{O}_{3}$} \\
\hline & $1300^{\circ} \mathrm{C}, 30 \mathrm{~min}$ & & $1300{ }^{\circ} \mathrm{C}, 120 \mathrm{~min}$ & & $1600{ }^{\circ} \mathrm{C}, 60 \mathrm{~min}$ \\
\hline Forsterite & $50.6 \% \pm 3.7$ & $\begin{array}{c}\text { Forsterite } \\
\text { Ferroan }\end{array}$ & $49.0 \% \pm 3.2$ & $\begin{array}{c}\text { Forsterite } \\
\text { Ferroan }\end{array}$ & $90.6 \% \pm 6.4$ \\
\hline Enstatite Ferroan & $37.6 \% \pm 3.0$ & Enstatite Ferroan & $38.1 \% \pm 3.0$ & Clinoenstatite & $4.5 \% \pm 0.6$ \\
\hline Magnesioferrite & $11.8 \% \pm 1.5$ & Magnesioferrite & $12.9 \% \pm 1.6$ & Magnesioferrite & $5.0 \% \pm 0.8$ \\
\hline \multicolumn{6}{|c|}{ Sample W8-10\% $\mathrm{Fe}_{2} \mathrm{O}_{3}$} \\
\hline & $1300^{\circ} \mathrm{C}, 30 \mathrm{~min}$ & & $1300{ }^{\circ} \mathrm{C}, 120 \mathrm{~min}$ & & $1600{ }^{\circ} \mathrm{C}, 60 \mathrm{~min}$ \\
\hline Forsterite & $45.5 \% \pm 3.4$ & $\begin{array}{l}\text { Forsterite } \\
\text { Ferroan }\end{array}$ & $45.4 \% \pm 3.4$ & $\begin{array}{l}\text { Forsterite } \\
\text { Ferroan }\end{array}$ & $87.4 \% \pm 6.2$ \\
\hline Enstatite Ferroan & $36.8 \% \pm 3.0$ & Enstatite Ferroan & $37.7 \% \pm 3.0$ & Clinoenstatite & $4.4 \% \pm 0.6$ \\
\hline Magnesioferrite & $17.7 \% \pm 1.2$ & Magnesioferrite & $16.9 \% \pm 1.1$ & Magnesioferrite & $8.3 \% \pm 0.9$ \\
\hline
\end{tabular}

This difference in the pyroxene content is probably the reason why sample W8 is the most favored, considering the addition of hematite, as compared with the other examined samples, and for all the measured major refractory properties, results most likely in better sintering among the co-existing olivine, magnesioferrite, and enstatite mineral phases. 


\section{Conclusions}

The production of refractories from the mining wastes by-products of the magnesite mine "Grecian Magnesites SA" (Gerakini, Chalkidiki, N. Greece) with hematite addition and the application of different thermal treatments was examined. In all products, both the apparent porosity $(\mathrm{AP} \%)$ and the water absorption (WA\%), are favored by the addition of hematite nanoparticles at $1300^{\circ} \mathrm{C}$ for $30 \mathrm{~min}$ and are suitable for producing refractory bricks. At the same time, the property of bulk density is increased, indicating the improvement of the products' refractoriness. The mechanical strength of the examined products was found to reach maximum values after the application of thermal treatment at $1300{ }^{\circ} \mathrm{C}$ for $120 \mathrm{~min}$. According to the respective XRD patterns from the products, it was revealed that the samples consisted mainly of olivine, pyroxenes and magnesioferrite, therefore resulting in the decrease of olivine and the pyroxenes' presence in the final product, alongside with a simultaneous increase of magnesioferrite content. Regarding the addition of hematite, it is clear that the addition of $10 \mathrm{wt} . \%$ hematite in all samples shows a deterioration of refractory properties when compared with the $5 \mathrm{wt} . \%$ addition. In general, the $5 \mathrm{wt} . \%$ addition of hematite nanoparticles improves the main refractory parameters of examined samples when the applied thermal treatment is $1300^{\circ} \mathrm{C}$.

The obtained results showed that the application of simple/preliminary thermal pretreatment at $850^{\circ} \mathrm{C}$ is not recommended, as it reduces the refractory properties. Regarding the examined higher firing temperature at $1600{ }^{\circ} \mathrm{C}$, the results showed a significant increase of the firing shrinkage parameters, while the mechanical strength was diminished to almost zero. In terms of heating time, when the thermal treatment was performed at $1300{ }^{\circ} \mathrm{C}$ for $120 \mathrm{~min}$, the products showed an increase of firing shrinkage of up to $3.0 \%$, while the mechanical strength parameter even doubled for some samples, when compared to the thermal treatment at $1300{ }^{\circ} \mathrm{C}$ for $30 \mathrm{~min}$.

The obtained results reveal that the initial specific mineralogical content is an important factor that affects the refractory properties of obtained products after the hematite addition, with the sample W8 showing the highest improvement of refractory properties as compared with the other examined samples. The collaborating magnesite mine company (Grecian Magnesite SA) is already applying the dunite products in numerous industrial uses such as the application of blast furnaces in slag conditioning, as EBT (eccentric bottom tapping) filler, and also in other refractory products such as in foundry sand, for sandblasting purposes, and mineral wool in fluidized bed combustion and $\mathrm{CO}_{2}$ sequestration. Overall, the scale-up potential with the addition of $5 \%$ hematite gives the specific advantage of improved mechanical strength to the products. Most notably, the addition of hematite nanoparticles causes the serpentinized samples to form bricks for application at $\leq 1300{ }^{\circ} \mathrm{C}$, turning them into value- added product suitable for application in a circular economy framework.

Supplementary Materials: The following supporting information can be downloaded at: https: //www.mdpi.com/article/10.3390/app12042094/s1, Table S1. Mineralogical content (wt.\%) of examined samples; the numbering of samples follows the same numbering as presented in the previous publication of Pagona et al., 2020 [1]; Table S2. Chemical composition of the four examined samples [1]; Figure S1. Satellite photo of the Gerakini mining district with the sites marked are presented; Figure S2. TG-DTA curves of samples W5, W6, W7 and W8 [1]; Figure S3. XRD diagram for the fired Bayoxide at $850{ }^{\circ} \mathrm{C}$; Figure $\mathrm{S} 4$. Optical microscope selected images (magnification: $\times 20$ ) of W5 sample at the different thermal treatments; Figure S5. Optical microscope selected images (magnification: $\times 20$ ) of W5PT sample at the different thermal treatments; Figure S6. Optical microscope selected images (magnification: $\times 20$ ) of W6 sample at the different thermal treatments; Figure S7. Optical microscope selected images (magnification: $\times 20$ ) of W6PT sample at the different thermal treatments; Figure S8. Optical microscope selected images (magnification: $\times 20$ ) of W7 sample at the different thermal treatments; Figure S9. Optical microscope selected images (magnification: $\times 20)$ of W7PT sample at the different thermal treatments; Figure S10. Optical microscope selected images (magnification: $\times 20$ ) of W8 sample at the different thermal treatments; Figure S11. Optical microscope selected images (magnification: $\times 20$ ) of W8PT sample at the different thermal treatments; 
Figure S12. Pseudobinary phase diagram of the system $\mathrm{MgFe}_{2} \mathrm{O}_{4}-\mathrm{Mg}_{2} \mathrm{SiO}_{4}$ caption from Abruz et al., 1981 [1]; Figure S13. XRD diagram of sample W5 fired at $1300{ }^{\circ} \mathrm{C}$ for $30 \mathrm{~min}$; Figure S14. XRD diagram of sample W5 fired at $1600{ }^{\circ} \mathrm{C}$ for $60 \mathrm{~min}$; Figure S15. XRD diagram of sample W5 with 5 wt. $\% \mathrm{Fe}_{2} \mathrm{O}_{3}$ fired at $1300{ }^{\circ} \mathrm{C}$ for 30 min; Figure S16. XRD diagram of sample W5 with 5 wt. $\% \mathrm{Fe}_{2} \mathrm{O}_{3}$ fired at $1600{ }^{\circ} \mathrm{C}$ for $60 \mathrm{~min}$.

Author Contributions: Conceptualization, V.Z. and M.M.; methodology, M.M.; software, X.N. and K.K.; validation, K.K., M.M. and A.Z.; formal analysis, K.K. and E.P.; investigation, E.P., K.K. and P.S.; resources, A.Z.; data curation, E.P. and K.K.; writing-original draft preparation, K.K.; writingreview and editing, M.M. and A.Z.; visualization, V.Z.; supervision, M.M. and A.Z.; project administration, A.Z.; funding acquisition, A.Z. All authors have read and agreed to the published version of the manuscript.

Funding: This research was funded by the European Union and Greek national funds through the Operational Program Competitiveness, Entrepreneurship and Innovation, under the call RESEARCHCREATE-INNOVATE (project code: T1EDK-03543).

Data Availability Statement: The authors confirm that the data supporting the findings of this study are available within the article and it's Supplementary Material. Raw data that support the findings of this study are available from the corresponding authors, upon reasonable request.

Conflicts of Interest: The authors declare that they have no conflict of interest.

\section{References}

1. Pagona, E.; Tzamos, E.; Griego, G.; Zouboulis, A.; Mitrakas, M. Characterization and evaluation of magnesite ore mining by-products of Gerakini mines (Chalkidiki, N. Greece). Sci. Total Environ. 2020, 732, 139279. [CrossRef]

2. Tzamos, E.; Bussolesi, M.; Griego, G.; Marescotti, P.; Crispini, L.; Kasinos, A.; Storni, N.; Simenonidis, K.; Zouboulis, A. Mineralogy and Geochemistry of Ultramafic Rocks from Rachoni Magnesite Mine, Gerakini (Chalkidiki, Northern Greece). Minerals 2020, 10, 934. [CrossRef]

3. Kucuk, I.; Boyraz, T.; Gökçe, H.; Öveçoğlu, M.L. Thermomechanical properties of aluminium titanate $\left(\mathrm{Al}_{2} \mathrm{TiO}_{5}\right)$-reinforced forsterite $\left(\mathrm{Mg}_{2} \mathrm{SiO}_{4}\right)$ ceramic composites. Ceram. Int. 2018, 44, 8277-8282. [CrossRef]

4. Cheng, T.W.; Ding, Y.C.; Chiu, J.P. A study of synthetic forsterite refractory materials using waste serpentine cutting. Miner. Eng. 2002, 15, 271-275. [CrossRef]

5. Il'Ina, V.P. Ceramic heat-insulation materials based on serpentinite. Glas. Ceram. 2013, 70, 12-15. [CrossRef]

6. Nemat, S.; Ramezani, A.; Emami, S.M. Possible use of waste serpentine from Abdasht chromite mines into the refractory and ceramic industries. Ceram. Int. 2016, 42, 18479-18483. [CrossRef]

7. Kusiorowski, R.; Wojsa, J.; Psiuk, B.; Wala, T. Influence of zirconia addition on the properties of magnesia refractories. Ceram. Int 2016, 42, 11373-11386. [CrossRef]

8. Emrullahoglu Abi, C.B.; Gürel, S.B.; Kilinç, D.; Emrullahoglu, F. Production of forsterite from serpentine-Effects of magnesium chloride hexahydrate addition. Adv. Powder Technol. 2015, 26, 947-953. [CrossRef]

9. Fedorenko, N.V.; Belikov, A.M. Reaction of iron oxides with serpentine chromite ores during heating. Refractories 1966, 7, 704-706. [CrossRef]

10. Rauta, P.R.; Sahoo, N. Properties enhancement of refractory bricks by incorporation of nano materials. In Proceedings of the 2015 International Conference on Nascent Technologies in the Engineering Field (ICNTE), Navi Mumbai, India, 9-10 January 2015. [CrossRef]

11. Manna, S.; Chakrabarti, T. Comparative Studies on Synthesis and Characterization of Titania and Iron Oxide Doped Magnesia from Indian Salem Magnesite. J. Mater. Sci. Chem. Eng. 2016, 4, 67-76. [CrossRef]

12. Gialanella, S.; Girardi, F.; Ischia, G.; Lonardelli, I.; Mattarelli, M.; Montagna, M. On the goethite to hematite phase transformation. J. Therm. Anal. Calorim. 2010, 102, 867-873. [CrossRef]

13. Raheem, Z. Standard Test Methods for Apparent Porosity, Water Absorption, Apparent Specific Gravity, and Bulk Density of Burned Refractory Brick and Shapes by Boiling Water; ASTM C20-00; ASTM International: West Conshohocken, PA, USA, 2017.

14. Pagona, E.; Kalaitzidou, K.; Zouboulis, A.; Mitrakas, M. Effects of additives on the physical properties of magnesite ore mining by-products for the production of refractories. Miner. Eng. 2021, 174, 107247. [CrossRef]

15. Gómez Rodríguez, C.; Das Roy, T.K.; Shaji, S.; Castillo Rodríguez, G.A.; García Quiñonez, L.; Rodríguez, E.; González, J.O.; Aguilar-Martínez, J.A. Effect of addition of $\mathrm{Al}_{2} \mathrm{O}_{3}$ and $\mathrm{Fe}_{2} \mathrm{O}_{3}$ nanoparticles on the microstructural and physico-chemical evolution of dense magnesia composite. Ceram. Int. 2015, 41, 7751-7758. [CrossRef]

16. Surendranathan, A.O. An Introduction to Ceramics and Refractories, 1st ed.; CRC Press: Boca Raton, FL, USA, 2014.

17. Benavidez, E.R.; Brandaleze, E.; Lagorio, Y.S.; Gass, S.E.; Martinez, A.G.T. Thermal and mechanical properties of commercial MgO-C bricks. Rev. Mater. 2015, 20, 571-579. [CrossRef] 
18. Bennett, J.P. High-Temperature Properties of Magnesia-Refractory Brick Treated with Oxide and Salt Solutions; Pergamon Press: Oxford, $\mathrm{UK}, 1985$.

19. Azhari, A.; Golestani-Fard, F.; Sarpoolaky, H. Effect of nano iron oxide as an additive on phase and microstructural evolution of Mag-Chrome refractory matrix. J. Eur. Ceram. Soc. 2009, 29, 2679-2684. [CrossRef]

20. Youhua, H.; Yimin, L.; Jia, L.; Hao, H.; Xiang, Z. Effects of sintering temperature and holding time on densification and mechanical properties of MIM HK30 stainless steel. Int. J. Metall. Met. Phys. 2018, 3, 22. [CrossRef]

21. Ambrúz, V.J.; Havlica, V.; Kanclir, E. Phase equilibria in the system $\mathrm{MgFe}_{2} \mathrm{O}_{4}-\mathrm{Mg}_{2} \mathrm{SiO}_{4}$. Chem. Pap. 1981, 35, 51-55.

22. Khisina, N.R.; Khramov, D.A.; Kolosov, M.V.; Kleschev, A.A.; Taylor, L.A. Formation of ferriolivine and magnesioferrite from Mg-Fe-olivine: Reactions and kinetics of oxidation. Phys. Chem. Miner. 1995, 22, 241-250. [CrossRef]

23. Acar, İ. Sintering properties of olivine and its utilization potential as a refractory raw material: Mineralogical and microstructural investigations. Ceram. Int. 2020, 46, 28025-28034. [CrossRef]

24. Rietmeijer, F.J.M.; Nuth, J.A.; Pun, A. The formation of Mg,Fe-silicates by reactions between amorphous magnesiosilica smoke particles and metallic iron nanograins with implications for comet silicate origins. Meteorit. Planet. Sci. 2013, 48, 1823-1840. [CrossRef]

25. Semberg, P.; Rutqvist, A.; Andersson, C.; Björkman, B. Interaction between iron oxides and olivine in magnetite based pellets during reduction at temperatures below $1000{ }^{\circ} \mathrm{C}$. Ironmak. Steelmak. 2011, 38, 321-328. [CrossRef]

26. Ivanova, T.I.; Maslov, V.N.; Gershkovich, S.I.; Iksanov, F.R.; Kovalenko, A.A.; Tsunaeva, A.V.; Markelov, S.A. Application of X-Ray diffraction methods for refractory raw material quality control. Refract. Ind. Ceram. 2021, 62, 51-59. [CrossRef]

27. Mielcarek, W.; Nowak-Woźny, D.; Prociów, K. Correlation between $\mathrm{MgSiO}_{3}$ phases and mechanical durability of steatite ceramics. J. Eur. Ceram. Soc. 2004, 24, 3817-3821. [CrossRef]

28. Goel, A.; Tulyaganov, D.U.; Shaaban, E.R.; Knee, C.S.; Eriksson, S.; Ferreira, J.M.F. Structure and crystallization behaviour of some $\mathrm{MgSiO}_{3}$-based glasses. Ceram. Int. 2009, 35, 1529-1538. [CrossRef]

29. Sarver, J.F.; Hummel, F.A. Stability relations of magnesium metasilicate polymorphs. J. Am. Ceram. Soc. 1962, 45, 152-156. [CrossRef]

30. Foster, W.R. High-Temperature X-ray diffraction study of the polymorphism of $\mathrm{MgSiO}_{3}$. J. Am. Ceram. Soc. 1951, 34, 255-259. [CrossRef]

31. Zulumyan, N.; Isahakyan, A.; Beglaryan, H.; Melikyan, S. A study of thermal decomposition of antigorite from dunite and lizardite from peridotite. J. Therm. Anal. Calorim. 2018, 131, 1201-2011. [CrossRef]

32. Torres, H.S.S.; Varajão, A.F.D.C.; Sabioni, A.C.S. Technological properties of ceramic produced from steatite (soapstone) residueskaolinite clay ceramic composites. Appl. Clay Sci. 2015, 112-113, 53-61. [CrossRef] 